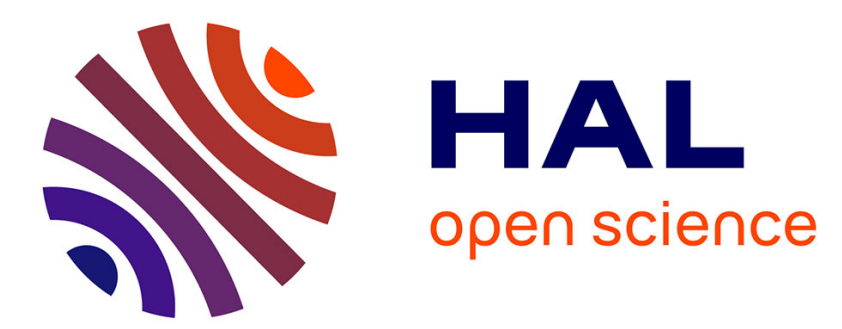

\title{
Health and the environment in ecological transition: the case of the permaculture movement \\ Laura Centemeri
}

\section{To cite this version:}

Laura Centemeri. Health and the environment in ecological transition: the case of the permaculture movement. The Relationship between Environment, Health, and Disease Toward a Multi-Spatial and Historical Approach, In press. hal-01613420

\author{
HAL Id: hal-01613420 \\ https://hal.science/hal-01613420
}

Submitted on 9 Oct 2017

HAL is a multi-disciplinary open access archive for the deposit and dissemination of scientific research documents, whether they are published or not. The documents may come from teaching and research institutions in France or abroad, or from public or private research centers.
L'archive ouverte pluridisciplinaire HAL, est destinée au dépôt et à la diffusion de documents scientifiques de niveau recherche, publiés ou non, émanant des établissements d'enseignement et de recherche français ou étrangers, des laboratoires publics ou privés. 
Centemeri, Laura, 2018, « Health and the environment in ecological transition: the case of the permaculture movement » in F. Bretelle-Establet, M. Gaille, M. Katouzian-Safadi (dir.), The Relationship between Environment, Health, and Disease Toward a Multi-Spatial and Historical Approach, Springer.

\section{Health and the environment in ecological transition: the case of the permaculture movement}

Laura Centemeri ${ }^{1}$

In this contribution my aim is to discuss how the permaculture movement promotes, through its concepts and practice, an understanding of human health as inseparable from the health of the environment - primarily intended as the health of the soil - and strictly dependent on the re-grounding of human subsistence activities within the environment of proximity ${ }^{2}$. This process of re-grounding should not be mistaken for self-sufficiency in providing for basic needs. Individual self-sufficiency is repeatedly defined as a pointless goal in the most influential writings on permaculture. ${ }^{3}$. Permaculturists are neither survivalists nor "peakists"4. The re-grounding of individual subsistence activities within the environment of proximity has the aim of sustaining the emergence of self-reliant communities. Moreover, this practical regrounding should be combined with a more engaging individual and collective process of "reinhabitation". By this term, introduced by American bioregional thinkers, permaculturists refer to a normative orientation of all life activities towards doing what is best for the longterm health and viability of one's own place of life ${ }^{5}$. More precisely, following Berg and Dasman "reinhabitation means learning to live-in-place in an area that has been disrupted and

\footnotetext{
${ }^{1}$ CNRS researcher, CEMS-IMM (CNRS/EHESS/PSL). Contact: laura.centemeri@ehess.fr

${ }^{2}$ This contribution discusses some of the issues I am currently exploring in an ongoing research program funded by the French ANR (SYMBIOS - Social Movements For The Transition Towards A Frugal Society, ANR-14-CE03-0005-01), and directed by Gildas Renou (University of Strasbourg).

${ }^{3}$ See on this point the analysis of Suh (2014a: 90) and the critique of the "Myth of selfreliance" as formulated by Toby Hemenway in his blog (http://tobyhemenway.com/107-themyth-of-self-reliance/). Hemenway is an influential permaculturist and the author of Gaia's Garden: A Guide to Home-Scale Permaculture, a best-selling permaculture publication. ${ }^{4}$ On "peakism" as the "ideology of peak oil believers" see Schneider-Mayerson (2015). ${ }^{5}$ Bioregionalism is an intellectual and political movement that stresses the importance of the place-based dimension of social life. Bioregions are usually defined on the basis of physical and environmental characteristics accounting for a form of territorial coherence (watershed boundaries, soil characteristics, etc.). On the theoretical and practical dimensions of bioregionalism see McGinnis (1999).
} 
Centemeri, Laura, 2018, « Health and the environment in ecological transition: the case of the permaculture movement » in F. Bretelle-Establet, M. Gaille, M. Katouzian-Safadi (dir.), The Relationship between Environment, Health, and Disease Toward a Multi-Spatial and Historical Approach, Springer.

\section{injured through past exploitation. It involves becoming native to a place through becoming} aware of the particular ecological relationships that operate within and around it. It means understanding activities and evolving social behavior that will enrich the life of that place, restore its life-supporting systems, and establish an ecologically and socially sustainable pattern of existence within it. Simply stated it involves applying for membership in a biotic community and ceasing to be its exploiter"s.

The idea of "living-in-place" through developing bonds to a specific "spot on the earth we can know intimately" can be more precisely understood in terms of the importance attributed to what I am going to discuss as emplaced modes of valuing the environment in orienting the "conscious design" of permacultural human settlements ${ }^{8}$. Through the concept of emplaced modes of valuation that I introduce here as an analytical tool, I want to point to those capacities of evaluation that rest on a corporeal, sensorial and affective understanding of what is "good" (or valuable) in the human-environment relationship. More in general through the lens of modes of valuation it is possible to go beyond a simple phenomenological understanding of the sense of place, to explore the process of re-inhabiting and living-in-place in terms of the recovery of actual evaluative capacities and practices guiding the way people engage with social and natural environments'.

My contribution is organized as follows. I first briefly present permaculture, as a concept and as a movement, its history and main traits. I then discuss the permacultural understanding of health, stressing the fact that the health of the person is conceived of as being dependent upon what permaculture should provide: the possibility of regaining a form of control over one's own "lifestyle and future" ${ }^{10}$. In permaculture, climate change, pollution, energy depletion, soil destruction, erosion and impoverishment are presented as sources of increasing uncertainty concerning the future. The permacultural response is to actively design our environments so as to create the conditions for authentic human flourishing, which is authentic in as far as it contributes to the well-being of the biotic community. The ecological transition is thus seen, potentially, as an opportunity to rethink human subsistence as a fundamental locus of

\footnotetext{
${ }^{6}$ Quoted in Aberley, 1999: 23

${ }^{7}$ Starhawk, 2002: 163.

${ }^{8}$ A permacultural human settlement is meant to yield "an abundance of food, fiber and energy for provision of local needs" with limited use of energy and natural resources. See Holmgren, 2011: XIX.

${ }^{9}$ See Tuan (1977) and Casey (1997) for a philosophical history of the concept of place.

${ }^{10}$ Mollison and Holmgren, 1978
} 
Centemeri, Laura, 2018, « Health and the environment in ecological transition: the case of the permaculture movement » in F. Bretelle-Establet, M. Gaille, M. Katouzian-Safadi (dir.), The Relationship between Environment, Health, and Disease Toward a Multi-Spatial and Historical Approach, Springer.

"commoning", challenging the capitalist way of dealing with human needs, including human health.

The idea of "controlling" the environment originates directly from a systemic thinking approach to environmental issues, which can prompt a utilitarian understanding of humannature relationships, quite close to the one supporting the mainstream vision of nature as "capital" providing "services". In the original framework of permaculture, however, utility to human beings and human control over nature are not intended as detached from a "sense of place", but, on the contrary, are grounded in the reflexive mobilization of capacities of "contemplation, reflection and experimentation" "11 . These capacities, I argue, imply recognizing the importance of the emplaced experience of the environment as a source of knowledge and specific normative orientations.

In this framework, humans are not seen simply as environmental stewards but as "responsible ecosystem managers" within, rather than separate from nature. The goal of the permaculture movement is not nature conservation, as is the case in the stewardship approach, but the active creation, by design, of the conditions for a perennial human-environment coevolution. To manage means here "(to) have a way, make do and work with nature" 12 . In classic permaculturists writings, this practical wisdom is expressed in terms of ethical principles of care, both of the people and of the environment, fair share and personal responsibility. These principles are considered as fundamental in order to have a "realistic rather than romantic understanding of what it means to live with and from nature" ${ }^{\prime 13}$. As a concluding remark, I will discuss the political implications of the permacultural vision of human health and human flourishing.

\footnotetext{
${ }^{11}$ Smith, 2011: XI.

12 The etymology of the word "management" is from the old French word "ménagement", from the Latin "manus agere", which means literally to lead by the hand ("manus" being the Latin for hand). In particular, Olivier de Serres, who is considered a founding father of French agroecology (Tassin 2011), published a book in 1600, Le théâtre d'agriculture et mesnage des champs, in which the concept of "mesnage" (management) is related to a practical philosophy of cultivating land through imitating nature. Catherine and Raphaël Larrère have introduced the concept of "have a way, make do and work with nature" (in French: faire-avec la nature) to qualify the arts of "managing" nature (in French: piloter) as opposed to the demiurgic techniques of exploiting nature.

${ }^{13}$ Holmgren 2011: 61.
} 
Centemeri, Laura, 2018, « Health and the environment in ecological transition: the case of the permaculture movement » in F. Bretelle-Establet, M. Gaille, M. Katouzian-Safadi (dir.), The Relationship between Environment, Health, and Disease Toward a Multi-Spatial and Historical Approach, Springer.

\section{The permaculture movement: a composite ethical framework for}

\section{ecological design activism in a world of energy descent}

Before being a movement, permaculture is, first of all, a holistic design system for the creation of sustainable human settlements. In other words, permaculture is "a practical in situ approach to creating collectively sustainable human settlements"14. From the ecological vantage point, permacultural "consciously designed landscapes" mimic the patterns and relationships found in nature. They draw inspiration from traditional models of ecological organization as well ${ }^{15}$. The idea is to "work with nature", and not against it, in order to create environments that are "healthful and nurturing" for humans and other species.

Permaculture is about "our relationships with, and the design and redesign of, natural resource management systems, so that they may support the health and well-being of all present and future generations", in a world considered to have declining energy and resource availability, and increasingly vulnerable to catastrophic events ${ }^{16}$. It is based on "assembling conceptual, material and strategic components in a pattern which functions to benefit life in all its forms" $"$.

Concretely, in its original formulation, a permacultural design results in the creation of an integrated and evolutionary agroforestry system that includes a variety of species (plant, animal, etc.), while being perennial (or auto-perpetuated) and beneficial to human beings and their biotic community. Animals can be explicitly included in this design and they are always considered from the perspective of the multiple functions they can provide, and never reduced to that of only providing food ${ }^{18}$.

It is important to stress, however, that permaculture is not simply reducible to a set of ecological engineering techniques, since permaculture tries not to separate the ecological and cultural dimensions implied in the design of sustainable human settlements. This means that permaculture is equally concerned with the design of dimensions of collective life pertaining

\footnotetext{
${ }^{14}$ Suh 2014a: 76.

${ }^{15}$ Holmgren, 2011: XVII. As reported by Suh (2014a: 79), Bill Mollison, one of permaculture's founding fathers, travelled extensively in the 1970s across India, Southwest Asia and peasant Europe where he could observe the organization of traditional farming systems that were thousands of years old.

${ }^{16}$ Hall, 2011 : V; Holmgren, 2002: XVI.

${ }^{17}$ Mollison, 1988: 69 (my emphasis).

${ }^{18}$ An example is the introduction of ducks in rice paddies as discussed by Suh (2014b): ducks feed on insects and weeds in paddies and fertilize rice plants.
} 
Centemeri, Laura, 2018, « Health and the environment in ecological transition: the case of the permaculture movement » in F. Bretelle-Establet, M. Gaille, M. Katouzian-Safadi (dir.), The Relationship between Environment, Health, and Disease Toward a Multi-Spatial and Historical Approach, Springer.

to cultural and political domains, such as education, health, collective decision-making, etc. In this sense permaculture is a holistic design system since ecological solutions are devised and developed in parallel with cultural and political experimentation that accompany them, and vice versa ${ }^{19}$.

Bill Mollison (1928-2016), a bio-agronomist, and David Holmgren (1955), his student, initiated permaculture in Tasmania (Australia), in the 1970s, in a socio-historical context marked by an increase in ecological struggles and countercultural movements, locally and globally ${ }^{20}$. New concepts such as "bioethics" were emerging in the intellectual sphere. In the original idea of Van Rensaaeler Potter, who first introduced it, bioethics implied an ecological understanding of the conditions of human well-being. A similar understanding of health is identifiable in permacultural thinking, as I am going to show ${ }^{21}$. Both Mollison and Holmgren were involved in the intellectual and socio-political effervescence of their time, and permaculture was initially intended mainly as a support for the many "back to the landers" who, in Tasmania as elsewhere, were moving from urban to rural areas to develop subsistence agriculture, often being totally unfamiliar with farming.

The word "Permaculture" originates from the contraction of the expression "Permanent agriculture" that appeared in the 1910s, in US agricultural science. As reported by Suh, the idea of "permanent agriculture" at this stage was not explicitly defined by the first American authors who introduced it: by this expression, they wanted to praise Oriental and Far Eastern agricultural systems in opposition to the kind of exploitative agriculture promoted by the US Department of Agriculture ${ }^{22}$. As reported by Fergusson and Lovell, in the 1920s the

\footnotetext{
${ }^{19}$ In this sense, to focus exclusively on the agroecological dimension of permaculture, and to assess the permaculture movement's relevance in terms of agricultural productivity, is somehow very partial. This is the approach primarily promoted, in France, by the INRA, which is not the one I am interested in developing in my own work.

${ }^{20}$ Tasmania has been the cradle of the first ecological political party, the United Tasmania Group, formed in March 1972. The constitution of this political subject is related to a movement of protest for the preservation of Lake Pedder (in the south-west part of the island) against the construction of a dam. The publication of reports such as The Limits to Growth and A Blueprint for Survival inspired the movement (Wall, 1998; Mulligan and Hill, 2001).

${ }^{21}$ For a discussion of Van Rensaaeler Potter's conception of bioethics see Gaille (2011). ${ }^{22}$ Suh, 2014a: 77.
} 
Centemeri, Laura, 2018, « Health and the environment in ecological transition: the case of the permaculture movement » in F. Bretelle-Establet, M. Gaille, M. Katouzian-Safadi (dir.), The Relationship between Environment, Health, and Disease Toward a Multi-Spatial and Historical Approach, Springer.

expression "permanent agriculture" was used in a somewhat different meaning in the US, to connote agricultural systems incorporating a high proportion of perennial species ${ }^{23}$.

Mollison and Holmgren's interest in both these declinations of "permanent agriculture" was motivated by the search for a low energy and high-yielding "perennial agriculture" to sustain "perennial culture", based on village self-reliance, in which there would be direct personal responsibility in activities of providing for basic needs: "to empower the powerless and create 'a million villages' to replace nation-states is the only safe future for the preservation of the biosphere" 24 . In this sense, "perennial" is not simply a synonym of "sustainable": perennial points to a more radical change in the social, economic and political organization that is needed to face the trajectory of energy descent, considered as unavoidable. It is for this reason that its founders consider permaculture "much more than a form of organic gardening": permaculture is a "positivistic" response to an environmental crisis that threatens "the wellbeing and even survival of the world's expanding population" 25 . It is important to highlight that permaculture is meant by Mollison and Holmgren as a necessarily collective endeavor, grounded, however, in a process of personal transformation involving the habits of everyday life.

Influenced by the reading of the political ecologist Ivan Illich, Mollison and Holmgren are critical of anonymous institutions taking control of basic needs. The main reason for their emphasis on relying on a network of close connections is the conviction of the unsoundness of the patterns of energy consumption of the industrial-capitalist model of social organization and the inevitable collapse to be expected. The goal of permaculture is not overall selfsufficiency but "the reduction of dependence on the wider industrial system" to create "interdependence within a locality" 26.

Although permaculture emerged inside academia, it has been viewed with suspicion by academics because of its strong interdisciplinary perspective and because it has been considered as utopian, from the point of view of mainstream agriculture. The divorce from academia over the last forty years has brought accusations of permaculture being a "pseudoscience", because it has not embraced more recent developments in ecological theory.

\footnotetext{
${ }^{23}$ Fergusson and Lovell, 2013. A perennial plant, or simply "perennial", is a plant that lives for more than two years.

${ }^{24}$ Mollison, 1988: IX

${ }^{25}$ Holmgren, 2011: XI, XV.

${ }^{26}$ Mollison and Holmgren, 1978: 12.
} 
Centemeri, Laura, 2018, « Health and the environment in ecological transition: the case of the permaculture movement » in F. Bretelle-Establet, M. Gaille, M. Katouzian-Safadi (dir.), The Relationship between Environment, Health, and Disease Toward a Multi-Spatial and Historical Approach, Springer.

Another accusation has been that of the idiosyncratic use of terminology ${ }^{27}$. Highlighting the lack of a substantive assessment, in peer-reviewed literature, of permaculture as an agroecological alternative, Ferguson and Lovell suggest considering permaculture as a form of "folk science", meaning by this that success in practice has not always been followed by indepth scrutiny ${ }^{28}$. The same authors also stress the "populist orientation" of permaculture literature, based on books written by non-academics and intended for a "popular" audience to whom the solutions to environmental and social crises are portrayed as both "simple and known"29.

This orientation towards lowering the access barriers to knowledge on the design of selfreliable human settlements is an important aspect of permaculture, as a practice oriented towards empowering people to take direct action (and responsibility) concerning a variety of everyday activities: permaculture "is about what we want to do and can do, rather than what we oppose and want others to change. This response is both ethical and pragmatic, philosophical and technical" ${ }^{\prime 30}$.

The transformation of everyday activities prompted by permaculture is, for Mollison and Holmgren, a pillar of broader social change seen as based, predominantly, on individual personal responsibility and voluntary action more than on the capacity to influence the policy-making process: permaculture aims for a "sustainable future" in which "empowered individuals" move "from being dependent consumers to becoming responsible and productive citizens" 31 .

\footnotetext{
${ }^{27}$ According to Ferguson and Lovell (2013) this is the case with the use, in permaculture literature, of the term "guild" to express mutually beneficial plant combinations, while the same concept means exactly the opposite in the scientific agrological vocabulary.

${ }^{28}$ Ferguson and Lovell, 2013. It should be noted, however, that starting from 2012, on the initiative of the British-based Permaculture Association (existing since 1983), a Permaculture International Research Network has been created in order to widen "the knowledge base of permaculture research", as part of an effort to increase links with universities and other academic institutions and policy makers in order to conduct high quality research projects. See the website https://www.permaculture.org.uk/research/1-team-who-we-are-and-what-wedo. I want to stress again that the agroecological dimension is just one dimension of permaculture and that it is somewhat limited to consider permaculture as simply an alternative way to practice agriculture.

${ }^{29}$ Ferguson and Lovell, 2013.

${ }^{30}$ Holmgren, 2011: XV. On permaculture and empowerment see Smith, 2002.

${ }^{31}$ Holmgren, 2011: XIX.
} 
Centemeri, Laura, 2018, « Health and the environment in ecological transition: the case of the permaculture movement » in F. Bretelle-Establet, M. Gaille, M. Katouzian-Safadi (dir.), The Relationship between Environment, Health, and Disease Toward a Multi-Spatial and Historical Approach, Springer.

Permaculture "pioneers", mostly itinerant permaculture teacher-activists have been disseminating permaculture through teaching and training, first in Australia and then worldwide. Today, permaculture is “one of Australia's most significant intellectual exports"32. The Permaculture Design Course (PDC), whose curriculum was codified in 1984, has, since then, been the prime vehicle for the global dissemination of permaculture ${ }^{33}$. As a transnational movement, permaculture has quite a loose form of organization, mostly structured through certified local/regional teaching and training institutions, grounded in local contexts. International and bioregional Permaculture Conferences (called Convergences) have been held regularly since the 1980s.

Beside the organization of these public gatherings and the offering of training opportunities, permaculture has been promoted via the creation of "demo-sites" (short for "demonstration sites"). Demo-sites are places in which the principles of permaculture have been applied to the design of human settlements that can range from simple gardens to ecovillages. These places are devoted to socio-ecological experimentation and permaculture teaching activities and they provide practical examples of applications of permacultural design principles. Permaculture activists do not valorize proselytism as a tool of dissemination but instead the small-scale realizations of the type of world they envision. This concrete "prefiguration" (Yates 2015) of permacultural ways of organizing human activities is considered of the highest importance to sustaining the movement's diffusion.

It is important, however, to distinguish the logic of demonstration from that of exemplarity, which is predominant in many "Lifestyle Movements (LMs)"34. In this respect similar to religious movements, many LMs highly valorize moral coherence between actions and ethical principles. The articulation between principles and actions is usually guaranteed by precepts, for example the elimination of animal products from one's diet in veganism. The permaculture movement too is grounded in ethical principles. These principles, however, are not translated into precepts: they are complemented by guidelines meant to orient problem-

\footnotetext{
${ }^{32}$ Holmgren, 2011: XX. See for the global dimension of the movement the website http://permacultureglobal.org/projects.

${ }^{33}$ Mollison copyrighted the word permaculture "for the purpose of consistent education": "The word 'permaculture' can be used by anyone adhering to the ethics and principles expressed herein. The only restriction on use is that of teaching; only graduates of a Permaculture Institute can teach 'permaculture' and they adhere to agreed-on curricula developed by the College of Graduates of the Institutes of Permaculture" (Mollison, 1988: IX) ${ }^{34}$ On LMs see Haenfler et al., 2012; on the logic of public demonstration see Rosental, 2013.
} 
Centemeri, Laura, 2018, « Health and the environment in ecological transition: the case of the permaculture movement » in F. Bretelle-Establet, M. Gaille, M. Katouzian-Safadi (dir.), The Relationship between Environment, Health, and Disease Toward a Multi-Spatial and Historical Approach, Springer.

solving design activities in specific situations, thus accounting for a variety of in situ practical permacultural realizations. This implies that there is no singular, identifiable permaculture lifestyle; the way in which a permaculturist lives can vary according to the specific local conditions of her place of living.

This "fluidity" is coherent with the bioregionalistic imaginary that inspires permaculture. As a "fluid object", the permaculture movement "isn't too rigorously bounded", “doesn't impose itself but tries to serve", "is adaptable, flexible and responsive" ${ }^{35}$. English is the "lingua franca" of the movement and a basic knowledge of English is an important skill for a permaculturist who wants to be actively involved in the transnational organization of the movement. National permaculture associations today ensure access to learning in local languages. Voluntary initiatives have started to take place in order to create a dictionary in which the main concepts and terms of permaculture are translated by permaculturists all over the world into more than fifteen different languages. To my knowledge, however, this work has not been accompanied by discussion concerning the cultural implications of different ways of translating permaculture concepts and especially its ethical principles.

Whether permaculture should be considered as a social movement - and of which kind - is an object for debate inside the self-same community of permaculture practitioners ${ }^{36}$. All depends on how one conceives of not only social movements but also political action. Permaculture can be understood as a practice-based form of activism, which can sustain a variety of political projects, from the more "radical" to the more "reformist" 37 . This accounts for a certain degree of political incongruity that is observable in the various initiatives referring to

\footnotetext{
${ }^{35}$ The reference is here to de Laet and Mol (2000: 226) and their analysis of the Zimbabwe Bush Pump as "fluid technology". I wish to thank Alexandre Gaudin for suggesting to me the category of fluidity as pertinent to describing the permaculture movement.

${ }^{36}$ See, for an example, the post "What permaculture isn't -and is" in Toby Hemenway's blog: http://tobyhemenway.com/668-what-permaculture-isnt-and-is/.

${ }^{37}$ As noted by Chatterton in the case of UK autonomous urban social center activists, permaculturists too share the same condition of "dwell(ing) both in the hoped-for and actual world": actions and living examples, not demonstrations and other forms of propaganda, are their main tools to "inspire people" to change. This implies paying attention to a "more complex and subtle understanding of anti-capitalist practice as not actually just 'anti-', but also 'post-' and 'despite-' capitalist' Chatterton, 2010: 1216; 1221. An example of a radical critique of capitalism, expressed through applying permacultural thinking and practice, is that promoted by the activist group known as the Laboratory of Insurrectionary Imagination. See http://www.labofii.net/.
} 
Centemeri, Laura, 2018, « Health and the environment in ecological transition: the case of the permaculture movement » in F. Bretelle-Establet, M. Gaille, M. Katouzian-Safadi (dir.), The Relationship between Environment, Health, and Disease Toward a Multi-Spatial and Historical Approach, Springer.

permaculture as a major influence and that I suggest understanding as an expression of the fluidity of permaculture as social movement.

This fluidity results from the composite ethical framework, inspiring permaculture, which represents, in my interpretation, the most original aspect of this movement. This ethical framework is based on care (of the earth and of people), distributive justice ("fair share"), and personal responsibility for choice (notably choice of procreation and consumption).

The acknowledged influence, at least in Holmgren's thinking, of Stewart Brand's Whole Earth Catalogue points to the importance, in permaculture, of the vision of the self as the ultimate driver of social change, in a world conceived of as an interconnected system of energy flows and information, in which technology is a potential countercultural force ${ }^{38}$. According to this vision, political transformation is the result not of agonistic politics but of empowered individuals becoming "comprehensive designers" who are able to see the "whole picture". In this sense, permaculture can be considered as an expression of "design activism", as theorized by the "design revolutionary" Victor Papanek for whom design "could revolutionize the living world" through "changing the relationship between humans and nature" and "help to heal social and ecological relations" 39.

Openly acknowledging Papanek's intellectual influence, David Holmgren defines design as "the conscious and intuitive effort to impose meaningful order" in complexity, thus reducing entropy. According to him: "design is not simply the result of rational, analytical and reductionist thinking, but also depends on our intuitive and integrative capabilities" ${ }^{, 40}$.

\footnotetext{
${ }^{38}$ I do not develop this point, since it is not central to the argument of the present essay. I just want to point out the proximity of permacultural thinking to some aspects of what Fred Turner (2006) describes as the peculiar political culture and worldview (based on personal integrity, individualism, collaborative sociability and soft technology) having given rise to "digital utopianism". Stewart Brand (born in 1938), a Californian journalist and entrepreneur, is, according to Turner, the key figure of junction, in the 1970s, between cybernetic counterculture and the emerging digital technologies hub in the Silicon Valley. The Whole Earth Catalog, published between 1968 and 1972, was founded by Brand "in order to help those heading back to the land find the tools they would need to build their new communities" (p. 5). One of his most famous quotes exemplifies the controversial aspects of his vision: "We are as gods and might as well get good at it".

${ }^{39}$ Anker, 2010: 81. Victor Papanek (1928-1998) is the author of Design For The Real World: Human Ecology and Social Change (New York: Pantheon Books, 1971).

${ }^{40}$ Holmgren, 2011: 14 (my emphasis). In this sense, we can say that permaculture inherits from the long history of relationship of design and ecological sciences, which dates back to early 1930s, and to the Bauhaus movement, when many biologists saw in modernist design a way to improve social health and the environment through the unifying of art and science. On
} 
Centemeri, Laura, 2018, « Health and the environment in ecological transition: the case of the permaculture movement » in F. Bretelle-Establet, M. Gaille, M. Katouzian-Safadi (dir.), The Relationship between Environment, Health, and Disease Toward a Multi-Spatial and Historical Approach, Springer.

The importance given to "intuition" and "integrative capabilities" based on extended in situ observation counteracts the considerable influence exerted on permaculture's vision by the thermodynamic perspective of Howard T. Odum's ecosystem ecology ${ }^{41}$. Most notably, permaculture keeps a "humanistic" approach to "whole systems design", based on the taking into account of the plurality of emotional and spiritual needs necessary for human flourishing, besides their biological and environmental needs ${ }^{42}$. Accordingly, nature is considered as "comprehensible only as sensation and system"43.

As I already pointed out, the apparently contradictory couple of principles such as "care and autonomy", "sensation and system", "strategy and harmony"44 "rationality and intuition" is omnipresent in the writings of the most influential permaculturists. The effort not to separate dimensions of reality and experience that the modern understanding of science, ethics and politics has disconnected can partially explain the difficulties that permaculture has been facing in academia while accounting for the practical success of the permaculture message. As Holmgren remarked: "for most people on the planet, the spiritual and rational still coexist in some fashion" 45 .

In my understanding, the innovative idea of permaculture is then to think about the environment as a network of dynamic, interacting and overlapping systems, while being, at the same time, what a person experiences as her place of living.

this history see Anker, 2010. See also the "mesological" analysis of eco-design developed by Petit 2015.

${ }^{41}$ Howard T. Odum (1924-2002) together with his brother Eugene P. Odum was a pioneer in the introduction of energetic systems theory to ecology. The approach to environmental issues they promoted was based on diagramming the flows of energy in the natural world as input and output circuits in a cybernetic ecosystem. All biological life (including human behavior) could thus be reduced to charts of energy circuits. This reductionist understanding of biological phenomena can justify an approach of techno-scientific management to governing societies, which is rather far from permaculture. In fact, where Odum conceived the ecosystem manager as situated outside the system, in permaculture, on the contrary, she is considered as part of the system. For a critique of the technocratic approach of Odum see Taylor, 1988.

${ }^{42}$ While Odum's approach was technocratic and heavily influenced by ecology applied to the recreation of ecosystems for the purpose of the sought after dream of space colonization (very influential in the 1950s and 1960s), permaculture's founders openly reject as meaningless these visions of enclosed and artificial life.

${ }^{43}$ Mollison 1988: 71 (my emphasis).

${ }^{44}$ This is the motto of the Permaculture Council for Europe (formerly European Permaculture Institute).

${ }^{45}$ Holmgren 2011:3. 
Centemeri, Laura, 2018, « Health and the environment in ecological transition: the case of the permaculture movement » in F. Bretelle-Establet, M. Gaille, M. Katouzian-Safadi (dir.), The Relationship between Environment, Health, and Disease Toward a Multi-Spatial and Historical Approach, Springer.

It is possible to intervene in such a complex web of interdependencies with design tools based on the imitation of nature and its observable patterns and meant to increase and support collective resilience and self-sustainability ${ }^{46}$. Of paramount importance then is the protracted and thoughtful observation of those "patches" in nature that are "wealthy" and "vibrant", in order to emulate them in landscape designs and repair the damage that has been done to natural systems by industrialized agriculture ${ }^{47}$.

The theoretical assumption behind the idea of "emulating nature" and "working with nature" is that, in nature, there are not only competitive and predatory relationships but "coexistence with no competition" and cooperative and symbiotic relationships improving the environment for each of the beings involved ${ }^{48}$. Human beings can design their activities so as to live in such a symbiotic, non-competitive, mutually benefitting way with their environments. In permaculture, human flourishing is not conceived of as conflicting with the environment: on the contrary, true human well-being, oriented by the consciousness of what we can call the "mesological condition" of human experience ${ }^{49}$, entails healthy and biodiverse environments. In this sense, permaculture shows the limits of a simplistic understanding of anthropocentrism, as an ethical posture opposed to ecocentrism. The specific ethics and normativity that guide permaculture are clearly anthropogenic but not exclusively anthropocentric, since they are deep-rooted in an understanding of human beings as being in a symbiotic relationship with the environment they inhabit ${ }^{50}$. As stated by Holmgren, permaculture is "unashamedly human-centred", since human beings have "the power and intelligence" to affect their own situation, and, conversely, the responsibility for their own situation "as far as possible" 51 . At the same time, human beings are conceived of as actors in a

\footnotetext{
${ }^{46}$ Mollison and Holmgren, 1978: 4. This attempt to base design on biology points to the very core of the modernist heritage of Bauhaus. See on this point Anker (2010).

${ }^{47}$ Michael, P. and W. Meachan, 2001. Permaculture design is organized according to concentric zones (from the house, the zone 0 , to the wilderness, the zone 5): the last zone is kept as a learning space, of no active human interference and just observation of spontaneous dynamics.

${ }^{48}$ Peter Kropotkin's work and his refutation of social Darwinism in The Mutual Aid : A Factor of Evolution (1902) had a strong influence on David Holmgren's early thinking. See Holmgren 2011:55.

${ }^{49}$ See Berque 2000.

${ }^{50}$ Where environment is intended in the sense of the French milieu. For a discussion of environmental ethics as necessarily anthropogenic, without being necessarily anthropocentric see Maris, 2010.

${ }^{51}$ Holmgren 2011: 6.
} 
Centemeri, Laura, 2018, « Health and the environment in ecological transition: the case of the permaculture movement » in F. Bretelle-Establet, M. Gaille, M. Katouzian-Safadi (dir.), The Relationship between Environment, Health, and Disease Toward a Multi-Spatial and Historical Approach, Springer.

complex environment whose ways of functioning are beyond the capacities of rational human understanding $^{52}$. This irreducible uncertainty requires the development of skills of empathic observation and intuition, together with small-scale and local experimentation. As stressed by Holmgren: "separating the useful from the useless in complex biological and human systems is (...) difficult" "53. In fact, "in attempting to fix any system, we may damage another that is working perfectly well" ${ }^{, 54}$. This implies that the emphasis on the need to take action and assume responsibility is, to a certain extent, always balanced (or contained), in permaculture, by the need to observe and let the systems develop, accepting feedback. Activity and passivity are both crucial.

According to this vision, what appears to us as a disease could be, in fact, a healthy response to some other disequilibrium in the system we are not aware of. This emphasis on "accepting feedback" and "letting the system evolve" has an influence on the way to conceive of human health as well, and especially, the practice of medicine.

\section{An ecological approach to human health: "healing" the soil for the healthy}

\section{development of human societies}

In line with the broader systemic understanding of nature, permaculture conceives of human health holistically: "we depend on good health in all systems for our survival" ${ }^{155}$. It is as important to "accept feedback" concerning human health as it is in nature. One should try to understand (mobilizing both systemic thinking and intuition) what a symptom points to, not to eliminate the symptom, as allopathic medicine is accused of doing. In other words, it is better not to interfere too much with natural processes. At the same time, active interference in the environment is necessary, in order to design environments that can evolve so as to guarantee, permanently, both the health of the person and that of the environment.

\footnotetext{
${ }^{52}$ The example mobilized in Permaculture Design Courses to illustrate this irreducible uncertainty of the extent of the system and mode of functioning is that of the mycorrhizas. Mycorrhizas are beneficial fungi, growing in association with plant roots, that greatly increase the absorptive area of a plant, acting as extensions to the root system. The extent of this area covered by the fungi is largely unknown. This implies that hidden associations can be at work in a natural system. Mycorrhizas are less frequent in cultivated soils, since the laboring of the soil destroys them: their beneficial action is replaced by the use of fertilizers.

${ }^{53}$ Holmgren 2011: 57.

${ }^{54}$ Holmgren 2011: 241.

${ }^{55}$ Mollison 1988: 3.
} 
Centemeri, Laura, 2018, « Health and the environment in ecological transition: the case of the permaculture movement » in F. Bretelle-Establet, M. Gaille, M. Katouzian-Safadi (dir.), The Relationship between Environment, Health, and Disease Toward a Multi-Spatial and Historical Approach, Springer.

In this systemic understanding, health depends, first of all, upon not only eating but also growing "healthy plants and animals", avoiding "biocides and pollutants", drinking "clean water or beverages" $"$. The link between the health of the environment and human health is primarily, but not exclusively, through food. According to Mollison: "Both dangers and benefits arise from our food. Natural levels of soil antibiotics may sustain us, and natural resistance to disease is in great part transmitted to us via food" ${ }^{, 57}$. However there are no food restrictions in permaculture, besides the general guideline to adapt food choices as much as possible to local conditions of permacultural food production. In this sense, practices of killing and eating animals (farm or wild animals) are possible if justified by local systemic dynamics.

The need to adapt food choices to local conditions of production implies that a change in how people eat becomes necessary, together with a change in how food is produced. For example, in order to increase local food self-reliance it may become necessary to shift to a diet less dependent on carbohydrates as well as to use alternative ways to access proteins. It is important to notice that these changes in the way of eating are not, for permaculturists, simply a lifestyle question, but, primarily, a form of ecological adaptation. To conceive of this adaptation simply as a lifestyle choice is somehow correct but superficial.

This adaptation and the acceptance of the constraints imposed by the objective of increasing local food self-reliance are not considered as harmful to health, quite the contrary.

Permaculturists consider the current epidemic of chronic pathologies (cancers, diabetes, etc.) in the western world as largely due to the huge deregulation of our eating habits, over the last 40 years. They consider the industrialization of agriculture and livestock farming' as the driver of this change ${ }^{58}$.

Local self-reliance also implies rediscovering, to learning and to sharing competences in the use of herbs for healing purposes. It implies, equally, de-hospitalizing birth and death ${ }^{59}$.

\footnotetext{
${ }^{56}$ Mollison 1988: 185.

${ }^{57}$ Mollison 1988: 184.

${ }^{58}$ Mollison and Holmgren 1978. It is important to stress that today the epidemic of chronic pathologies is not confined to the North of the planet but it has progressively become a plague in the South as well, due to the deregulation of local eating habits caused by the invasion of cheap "junk" food in local markets. See Saligram and Nugent (2016) and Coste (2014).

${ }^{59}$ In Holmgren's "Permaculture Flower" - a diagram showing synthetically the key domains that require transformation to create a sustainable culture - health is conceived together with "spiritual wellbeing" as requiring the exercise of yoga or other body/mind/spirit disciplines,
} 
Centemeri, Laura, 2018, « Health and the environment in ecological transition: the case of the permaculture movement » in F. Bretelle-Establet, M. Gaille, M. Katouzian-Safadi (dir.), The Relationship between Environment, Health, and Disease Toward a Multi-Spatial and Historical Approach, Springer.

More generally, permaculture is sympathetic to an approach to health in which preventive measures (hygiene of life) and capacities of self-care are of crucial importance. Self-care is, in fact, the "soil" in which people care and earth care can grow: according to Holmgren "to be able to contribute to a wider good, one must be healthy and secure" $" 60$. In this respect, permaculture's approach to health emphasizes, first of all, individual responsibility in self-care, as well as the importance of local, self-organised networks of health support. As I have already pointed out, permaculture shares, with other movements that are critical of both the industrialization/standardization and the marketization of basic needs (health care included), a critical approach towards large, anonymous institutions (such as the market or the State) as providers for basic needs. Some authors argue that through reinforcing a vision of self-disciplined individuals and self-reliant ordered communities, while denouncing the State as incapable (or corrupted), these movements reproduce neoliberal subjectivities and practices and they can easily be co-opted in projects of dismantling public health programs, with the consequential contribution to the further increase of social inequality. At the same time, other authors underline the possibility of strategic alliances with other actors, engaged in struggles against the inequalities produced by capitalist social relations, as a way to create and "feed" alternative "imaginaries" (notably through the framework of the "commons") ${ }^{61}$. Truth is that public actors often consider these alternative approaches to health as a promotion of a "do-it-yourself" health judged as potentially harmful to the person and the collectivity, since it jeopardizes the very idea of public health itself ${ }^{62}$.

the practice of holistic medicine, home birth and "dying with dignity". See Holmgren, 2011: XX.

${ }^{60}$ Holmgren 2011: 7.

${ }^{61}$ See on this point the analysis that Calvário and Otero (2015) develop concerning, more in general, "Back-to-the-landers". There are various examples of such alliances, as the initiatives reclaiming themselves from a perspective of "Liberation permaculture", the "Black Permaculture Network", the previously mentioned "Laboratory of Insurrectionary Imagination".

${ }^{62}$ For example, when alternative visions on health lead to the refusal of vaccinations. Moreover, the alternative health practices promoted as holistic approaches are denounced, sometimes, as the place for potentially sectarian "deviations" which require a form of monitoring. See, in particular concerning France, the activity of the Interministerial Mission against Sectarian Deviations (Miviludes, http://www.derives-sectes.gouv.fr/,) that monitor alternative therapeutic practices in health, in order to repress sectarian deviations and inform the public on the existence of this risk. 
Centemeri, Laura, 2018, « Health and the environment in ecological transition: the case of the permaculture movement » in F. Bretelle-Establet, M. Gaille, M. Katouzian-Safadi (dir.), The Relationship between Environment, Health, and Disease Toward a Multi-Spatial and Historical Approach, Springer.

Reclaiming a holistic approach to health, in which the link between health and environment is crucial, is not particularly specific to permaculture, as compared to other intellectual and practical movements supporting alternative visions of health and education (like anthroposophy, for example). What is specific to permaculture, I argue, is the idea of promoting health through providing the possibility of living a meaningful life, starting from the opportunity to carry out meaningful work. Gardening for self-production should not be considered simply as a way of increasing self-reliance: according to Mollison, gardening is a form of "meditation"63. More generally, to produce one's own food and fibers, according to permaculture principles, provides a meaningful experience of work, based on a sense of wholeness: "rather than the menial and repetitive labour of sowing, ploughing and reaping in a labour-intensive annual crop system, work in the permaculture system usually involves observation and control rather than power functions" ${ }^{\prime 64}$.

This contemplative - one could say passive - dimension that is highly valued in permaculture (as part of observation, and as a result of a humble attitude towards the complexity of nature) is always balanced by a vision of permaculture as "empowering" people and helping them to take action. As expressed by Mollison: "I sometimes think that the only real purpose of an initial design is to evolve some sort of plan to get one started in an otherwise confusing and complex situation. If so, a design has a value for this reason alone, for as soon as we decide to start doing we learn how to proceed" ${ }^{\prime \prime}$.

According to its founders, permaculture is beneficial especially since it provides the tools to engage in direct action to address basic problems, thus giving the opportunity to recover a sense of control over one's own life and escaping the paralysis of "paranoia", which can be induced by challenges apparently beyond our control such as climate change, energy transition etc.: "perhaps the most valuable product of a city devoted to permaculture would be peace of mind; a paranoia pervades cities and it is a product of helplessness in the face of approaching energy shortages and uncertain futures" ${ }^{\mathrm{g}}$.

It is especially at the urban level that permaculture is considered as an activity that can have a decisive impact on health: "a city or community involved in permaculture is taking an

\footnotetext{
${ }^{63}$ Mollison 1988: 183.

${ }^{64}$ Mollison and Holmgren 1978: 9. On the use of agriculture for therapeutic and "empowering purposes, and its connection with countercultural movements, see Doidy (2012).

${ }^{65}$ Mollison 1988: 47.

${ }^{66}$ Mollison and Holmgren 1978: 90.
} 
Centemeri, Laura, 2018, « Health and the environment in ecological transition: the case of the permaculture movement » in F. Bretelle-Establet, M. Gaille, M. Katouzian-Safadi (dir.), The Relationship between Environment, Health, and Disease Toward a Multi-Spatial and Historical Approach, Springer.

important step towards controlling its destiny; consultancy groups can advise and monitor dangerous substances in the environment; irresponsible industry and public authority is thus identified and can be regulated or replaced. People, seeing a food resource develop nearby, are relieved of a great deal of their anxiety about their future, and can become actively involved in constructive work which assists community survival. It cannot be too much stressed that this factor alone will greatly assist community health" ${ }^{\text {}}$.

The refusal to separate "human survival" from the "survival of natural systems" implies the development of " general earthcare ethics" because all life is "our family"68. This "general earthcare ethics" is rooted in the care of soil. In Holmgren's words "care for the earth can be taken to mean caring for living soil as the source of (terrestrial) life and for which we have the greatest responsibility" 69 . The question of soil is considered from "viewpoints or sets of values" that are quite different if compared to the current ones. The state of the soil becomes "the best measure of the future health and well-being of society" $"$. That is the reason why permaculture is not concerned exclusively with "preserving" but, more broadly, with the "healing" and regeneration of long-term soil fertility. Rehabilitative work to heal damage to ecosystems is what permaculturists are meant to do, as a form of stewardship "in which one leaves the land in better shape than it was when one received it". This "veneration of humus" is about increasing "the biological capacity of soil for the benefit of future generations" The almost religious tone that shows through these quotations concerning the soil reveals the influence that the environmental philosophies of Taoism and Zen Buddhism had on the formulation of the original concepts of permaculture. This also explains the many similarities between feng-shui and permaculture. As remarked by Suh: "the proponents of both feng-shui and permaculture consider soil to be the interface between non-living mineral earth and the atmosphere, and thus the most important site of interaction for all terrestrial life, inclusive of humankind" ${ }^{, 72}$.

\footnotetext{
${ }^{67}$ Mollison and Holmgren, 1978: 94. The initiatives known today as "Transition towns" have been firstly promoted, in the UK, by a permaculture designer, Rob Hopkins. See Hopkins, 2011. Transition towns have created a network: see https://www.transitionnetwork.org/.

${ }^{68}$ Mollison 1988: 3

${ }^{69}$ Holmgren 2011: 5 .

${ }^{70}$ Holmgren 2011: 5 .

${ }^{71}$ Holmgren 2011: 10.

${ }^{72}$ Suh, 2014a: 81 .
} 
Centemeri, Laura, 2018, « Health and the environment in ecological transition: the case of the permaculture movement » in F. Bretelle-Establet, M. Gaille, M. Katouzian-Safadi (dir.), The Relationship between Environment, Health, and Disease Toward a Multi-Spatial and Historical Approach, Springer.

As pointed out by Mollison, the only places where the soil is conserved or increased, apart from "uncut forests" and "under the quiet water of lakes and ponds", are "the prairies and meadows of permanent plants" and "where we grow plants with mulched or non-tillage systems" $" 73$. However, how to care for the soil remains partially open to interpretation, since "soils defy precise treatment", being the result of a "very long and varied history"74. According to Holmgren, to care for the soil, as a way to care for the earth, means "looking after home, place, country, or territory, as understood by indigenous cultures and, more recently, through the concept of bioregionalism" ${ }^{\text {, }}$. This is why I argue that at the core of the permacultural understanding of health, conceived as inextricably human and environmental flourishing, there is the process of reinhabiting. I propose to understand and investigate this process in terms of the recovering, or developing, at the personal and collective levels, of emplaced modes of valuing our relationship to the environment.

\section{Recovering a "sense of place" through learning and teaching emplaced modes of valuing}

\section{the environment}

As Lockyer and Veteto highlight, bioregionalism, permaculture and ecovillages can be considered as "three interrelated and often overlapping ecotopian social movements" "76. The aspect I am interested in, is the convergence of permaculture, bioregionalism and ecovillages in stressing the importance of reinhabiting: "Reinhabitation entails a process whereby individuals and communities decide to commit themselves to a particular bioregion and live 'as if' their descendants will be living there thousands of years into the future. (...)

Bioregionalists often take the indigenous societies of their bioregions as models of long-term inhabitation and sustainability, but work within their own cultural traditions, with a sense of

\footnotetext{
${ }^{73}$ Mollison 1988: 183.

${ }^{74}$ Mollison 1988: 182.

${ }^{75}$ Holmgren 2011: 5 (my emphasis).

${ }^{76}$ Lockyer and Veteto, 2013: 26. Lockyer and Veteto focus their analysis on the more recent American tradition of bioregionalism, that emerged in the 1970s and expressed in the writings of such authors as Raymond Dasmann, Peter Berg, Gary Snyder and Stephanie Mills. However, as pointed out by Aberley (who on this is following the analysis of Fitzpatrick Sale), American regionalists such as Howard Odum and Lewis Mumford can be considered as precursors of bioregionalist thinking, together with European regionalists such as Paul Vidal de la Blache and Patrick Geddes. See Aberley, 1999. Geddes is, for example, a major influence in the bioregionalist approach developed by the "territorialist" Italian thinker Alberto Magnaghi. See Magnaghi, 2014.
} 
Centemeri, Laura, 2018, « Health and the environment in ecological transition: the case of the permaculture movement » in F. Bretelle-Establet, M. Gaille, M. Katouzian-Safadi (dir.), The Relationship between Environment, Health, and Disease Toward a Multi-Spatial and Historical Approach, Springer.

dynamism that does not reify or essentialize traditional place-based cultures"77. To quote Holmgren: "Wherever we live, we must become new indigenes"

An in-depth discussion concerning the political pitfalls and snares of such an idea is beyond the scope of my contribution. What seems to me important to stress, for the argument I have been developing so far, is that these movements reclaim the necessity of thinking about politics, but also about the economy and about health, from "the standpoint of place" while having, at the same time, an emancipatory vision: "anyone of any race, any religion, or origin is welcome, as long as they live well on the land... This sort of future culture is available to whoever makes the choice, regardless of background"79.

The idea of choosing to be committed to a place (and live well on it), while being engaged in nurturing a global network ensuring certain forms of circulation between "localities" (so as to share knowledge, experience and to support struggles for global justice $)^{80}$, is seen, by these authors, as a possible libertarian reaction against the standardization of space and time, and the ever-increasing dominance of commensuration through the generalized marketization of all aspects of life induced by global capitalism. It also represents a challenge to the politically reactionary anti-modernist understanding of the place, as the homeland determining the entirety of one's identity, past, present and future, in an immutable natural order of things. In my understanding, in order to fully appreciate the originality of the political vision of "reinhabiting", as well as the specific political challenges that this idea raises, it is necessary to develop a (theoretical, analytical and empirical) sensibility to the "emplaced" dimension of social processes, to which the emergence of what is described in literature as the phenomenological "sense of place" is, I argue, connected ${ }^{81}$. In particular, I contend that it is crucial to develop a (theoretical, analytical and empirical) sensibility to emplaced modes of valuation orienting how human beings engage with their environments.

\footnotetext{
${ }^{77}$ Lockyer and Veteto, 2013: 32.

${ }^{78}$ Holmgren 2011: 211.

${ }^{79}$ Using the words of Gary Snyder, an influential deep ecology American thinker and poet, quoted by Lockyer and Veteto: 34 .

${ }^{80}$ Quoting Gieryn (2000:472): “"Locality' is as much phenomenological as spatial, achieved against the ground of globalization or nationalisation".

${ }^{81}$ Reams of words have been devoted, in social sciences, to define, clarify, criticize and challenge the distinction between space and place. For an extensive review of the literature oriented towards understanding the relevance of this distinction for sociology see the article by Gieryn (2000).
} 
Centemeri, Laura, 2018, « Health and the environment in ecological transition: the case of the permaculture movement » in F. Bretelle-Establet, M. Gaille, M. Katouzian-Safadi (dir.), The Relationship between Environment, Health, and Disease Toward a Multi-Spatial and Historical Approach, Springer.

In the work I am currently developing with Gildas Renou, we define as a "mode of valuation" a culturally recognizable assemblage of sensorial and affective dispositions, cognitive capacities and practical operations that are mobilized by agents, in the course of action, in order to judge what should count as valuable in a given situation and to evaluate, or test, this judgment $^{82}$.

Let me give an example in order to clarify this point, taken from my own fieldwork. The direct observation of a variety of permaculture initiatives (training courses; urban and rural projects; local, national and international meetings), in a plurality of localities, is a necessary complement to the analysis of permaculture discourses and writings. Through observation, it is possible to examine how permacultural principles, tools and instruments are appropriated in practice, put to work and sometimes transformed in order to respond to the specific "normative expectations" of local actors ${ }^{83}$. Multi-site ethnography is necessary to understand how the bioregionalist imaginary of the permaculture movement is actually taking shape, or not, in the various localities in which permaculture initiatives are spreading. However, beside the differences one can observe in situ, I contend that there is a common feature, accounting for the movement to be recognizable as having an identity, which is the importance attributed to teaching and training activities in order to transfer not simply techniques but, more broadly, a specific evaluative framework.

The example I am going to discuss is related to my participant observation of a seminar on "designing a food forest", organized by the Italian association of permaculture (Milan, July $2015)^{84}$.

The teacher (a former president of the Italian association of permaculture and an experienced permaculture teacher) introduced the course telling the participants that in order to address the issue of "how to design a food forest", it is necessary, first, to address the question of "why we want to design a food forest". He then invited the participants to do the following exercise:

\footnotetext{
${ }^{82}$ We define as valuation the identification/selection by an agent of what should count as valuable in a given situation, in a way that can be communicated and understood by others. This means that what counts as valuable relies on a widely shared cultural understanding of what is worth and what "matters". We define as evaluation the judgment of a situation according to a certain criterion of valuation, by means of convenient and appropriated activities. See Centemeri and Renou (2015).

${ }^{83}$ On the concept of "normative expectations" see Dodier and Barbot (2016).

${ }^{84}$ The concept of "food forest" is based on the idea of designing a garden emulating a real forest functioning in order to create a low-maintenance "forest garden", filled with the food plants and trees that one wants or is able to grow. See Jacke and Toensmeier 2005.
} 
Centemeri, Laura, 2018, « Health and the environment in ecological transition: the case of the permaculture movement » in F. Bretelle-Establet, M. Gaille, M. Katouzian-Safadi (dir.), The Relationship between Environment, Health, and Disease Toward a Multi-Spatial and Historical Approach, Springer.

to list the "good reasons" for designing a food forest. Students were divided in small groups and each drew up a list of good reasons. A spokesperson for each group presented their list to the plenary assembly of participants.

A common list of "good reasons" to design a food forest was compiled at the end of the exercise by the teacher, starting from what participants said during this specific course but also from what previous students in previous, similar courses had said.

The list of good reasons for creating a food forest thus compiled spanned from "the production of oxygen for the planet", "the preservation of traditional species" or "the recovering of environmentally damaged areas and the preservation and protection of soil", to "becoming more resilient", "having fun and let animals have fun too", "letting something spontaneous happen", "enjoying sounds", "sharing the experience of the forest with friends" etc.

I propose to understand these "good reasons" to design a food forest as reasons according to which the food forest can be considered as something good, something that matters and is valuable. They are reasons to value the forest and they point to practical ways in which to valorize the forest. The verb "to valorize" is used to indicate that a material reality is transformed or simply arranged according to a certain definition of value, in order to stabilize as much as possible a certain value experience. Only once the "good reasons" to value are clearly stated, can it be possible to start to actually draw a design of the food forest, which is meant to incorporate these evaluative judgments so as to valorize the environment accordingly. Quoting Mollison and Holmgren: "Net yield is only one value to consider. In commercial agriculture all value is converted into money (...). In subsistence agriculture human needs determine the value of yields and since our needs are diverse, so the yields should be diverse" $" 85$.

What I am interested in, in this example, is the fact that, in Permaculture Design Courses, there is not just a transmission of technical knowledge on agroforestry and eco-design. Permaculture courses are meant to communicate certain criteria (and not others) defining what should count as valuable and worthy in our ways of engaging with the environment. These criteria are what we call, with Renou, "modes of valuation". They go with the teaching and learning of the knowledge, skills, capacities and sensibilities needed to evaluate (and valorize) according to these very diverse definitions of the valuable. It is important to notice

${ }^{85}$ Mollison and Holmgren 1978: 7 (my emphasis). 
Centemeri, Laura, 2018, « Health and the environment in ecological transition: the case of the permaculture movement » in F. Bretelle-Establet, M. Gaille, M. Katouzian-Safadi (dir.), The Relationship between Environment, Health, and Disease Toward a Multi-Spatial and Historical Approach, Springer.

that I am using here the term "evaluation" to point to both formalized procedures to assess the value according to conventional categories and to practices through which value is appraised by way of shared or customary local criteria. In both cases, evaluation does not always imply quantification $^{86}$.

When speaking about emplaced modes of valuing the (socio-ecological) environment, we point to a form of knowledge and appreciation of the relationship of human beings to their environments that rests on the interrelationship of body-mind-environment and that takes place primarily at the esthetic level ${ }^{87}$. This same relationship, however, can also be understood and appreciated through distancing, when "the valuable" is independent from the emplaced experience. In this case, we speak about modes of valuation through distancing and the key operation that has to be performed in order to evaluate and valorize is that of establishing equivalences, often but not necessarily by way of quantification. This implies the devising of tools and techniques of commensuration ${ }^{88}$. In emplaced modes of valuation, what counts as valuable in the relationship with the environment is, instead, some kind of sensorial and affective good, and evaluation rests on a judgment based on an embodied felt proximity to this (felt) good. In order to share this mode of (e)valuation with others, sensory skills and sensibilities must be developed and trained.

Going back to our list of different reasons to value a "food forest", "sharing the experience of the forest with friends" or "enjoying sounds" are reasons to value a food forest where what counts as valuable is based on the body experiencing the affective and aesthetic influences of a specific environment and situation, and appreciating this environment and situation for these

\footnotetext{
${ }^{86}$ I adopt an approach to evaluation as a fundamental dimension of human action and not simply as a specialized field of activity. For an understanding of evaluative activities as fundamental to human existence see Canguilhem (2006).

${ }^{87}$ In the sense of the level of aesthesis, the perception and the corporeal sensibility we draw the concept of "being emplaced" from the vocabulary of the "phenomenology of place and space" developed by authors such as Edward Casey, Doreen Massey, Tim Ingold, and Sarah Pink. See in particular Pink 2009. We re-interpret this tradition through the lens of the "mesological" approach developed in France by Augustin Berque (2000). A major influence in our work is the "pragmatic sociology of proximity (sociologie pragmatique du proche) developed by Laurent Thévenot and Marc Breviglieri. See Thévenot (2007).

${ }^{88}$ Commensuration takes place in the real world and socio-technical "investments in forms" are devised in order to actually transform things that are different (in the personal experience that we have of them) into things that can be represented as the same (in value). These "investments" are meant to endure through time and space. Commensuration can imply, but not necessarily, the use of numbers. See on this Thévenot, 1984, 2009.
} 
Centemeri, Laura, 2018, « Health and the environment in ecological transition: the case of the permaculture movement » in F. Bretelle-Establet, M. Gaille, M. Katouzian-Safadi (dir.), The Relationship between Environment, Health, and Disease Toward a Multi-Spatial and Historical Approach, Springer.

particular sensorial and affective qualities. The valuation according to which what is valuable is "spontaneity" and "unexpectedness" in the interactions and collaborations between species in the ecosystem also relies on a form of knowledge dependent on the interrelationship of body-mind-environment and accounting for a type of observation that can detect such things as "spontaneity" in a specific environment. If we consider the valuation expressed through defining as a good reason to create a food forest the "production of oxygen for the planet" or the "preservation of traditional species", what is valuable is defined in terms of an abstract representation of the environment, of its qualities and of its beings. No interrelationship of body-mind-environment is necessary here in order to be able to judge what is valuable.

We contend that it is possible to identify a variety of emplaced modes of valuation but this normative richness (or plurality) has been rather neglected by social sciences. The ease felt through the familiarity with "dwelled-in" places, people we are close to (emotionally) and appropriate tools and objects is a mode of emplaced valuation quite different from the excitement felt through the exploration of the newness or the resonance felt through attuning to an ambience ${ }^{89}$.

The task of exploring these modes of emplaced valuation confronts us with methodological challenges but it is crucial in order to understand what is at stake, practically and politically, in the process of reinhabiting, that is so crucial to the vision promoted by permaculture.

In my understanding, the capacity to care could be more precisely intended as related to the development of the awareness of the various emplaced modes of valuing we can experience in our relationship with the socio-ecological environment. But this awareness needs to be developed together with the consciousness of the plurality of detached modes of valuation or of modes of establishing an equivalence - on which rest the possible diverse understandings of what justice means ${ }^{90}$.

Only if both these capacities of emplaced (e)valuation and detached (e)valuation of our relationship with the environment have been developed and trained, does it become possible to design permaculturally healthy human settlements. They are healthy because they are designed according to principles in which the principle of earth care is not considered separately from the principles of "people care" and "fair share".

\footnotetext{
${ }^{89}$ See Breviglieri (2012), Auray and Vetel (2013), Thibaud (2011).

${ }^{90}$ See, for an example of the different understandings of justice that can guide an NGO's action of post-disaster neighborhood revitalization, the case-study on post-Katrina New Orleans in Allen (2013).
} 
Centemeri, Laura, 2018, « Health and the environment in ecological transition: the case of the permaculture movement » in F. Bretelle-Establet, M. Gaille, M. Katouzian-Safadi (dir.), The Relationship between Environment, Health, and Disease Toward a Multi-Spatial and Historical Approach, Springer.

The permacultural design tries to valorize, in the socio-ecological organization of human communities (from the house to the bioregion), a wide variety of emplaced and detached goods, relying on the relationship human beings build and shape with their socio-ecological environments. The purpose is that of creating the condition both for human well-being and for the health of the biotic community.

However, how concretely these plural ways of valuing can coexist harmoniously, and the role played by different local cultures in sustaining or hampering the conditions for this coexistence, is a question open to further investigation, through the in-depth analysis of local permaculture initiatives. This also implies investigating the extent to which innovations are able to circulate in the permaculture movements, given their solid local anchoring.

In conclusion, I would like to point to some problematic aspects, raised by the ambitious value pluralism that informs permaculture's ethical framework.

In the creation of a modern society based on a modern understanding of justice and a modern public sphere, those modes of valuation through distancing in which "the valuable" is supposed to have universal validity (with science playing the role of establishing the terms of this universality) have been endowed with an unconditional privilege of legitimacy. This has implied the progressive eclipse of the acknowledgment of the role that emplaced modes of valuation play in social life as well as the progressive standardisation of the wide variety of local modes of valuation that have always been crucial to the bioregional organization of socio-ecological communities (Doidy 2008).

When they haven't been seen as the source of various dangers or impediments to the expression of "modern values", emplaced modes of valuation have been confined to the domain of an indistinct "informal", "tacit", "embodied" dimension of social life.

As the permaculture approach to the design of human settlements tries to emphasize, emplaced modes of valuation are of crucial importance in the healthy socio-ecological organization of human communities. At the same time, they are disruptive of a certain modern understanding of the relationship between society and nature, which goes hand in hand with a certain modern understanding of the relationship between knowledge and experience and between reason and emotion. Permaculture thinking tries to overcome these dichotomies, one of them being particularly difficult to deal with: that opposing emancipation to spirituality ${ }^{91}$.

\footnotetext{
${ }^{91}$ I cannot develop this point. I would like nevertheless to point out that emplaced modes of valuation are crucial in certain forms of basic spiritual experience, as Mollison implicitly
} 
Centemeri, Laura, 2018, « Health and the environment in ecological transition: the case of the permaculture movement » in F. Bretelle-Establet, M. Gaille, M. Katouzian-Safadi (dir.), The Relationship between Environment, Health, and Disease Toward a Multi-Spatial and Historical Approach, Springer.

This disruption is necessary to imagine a post-capitalist future, but it can be turned into the reactionary destruction of fundamental acquisitions of modernity, in terms of social justice and individual freedoms. At the same time, it is fundamental to be aware of the radical and insurmountable tensions existing between emplacement and detachment ${ }^{92}$. Only with this awareness, is it possible to fully measure the originality and the potentialities of the permaculture movement.

\section{References}

Aberley, D. 1999. "Interpreting bioregionalism: A story from many voices". In McGinnis V. (ed.) Bioregionalism. London: Routledge. 13-42.

Allen, B. 2013. "Justice as Measure of Nongovernmental Organization Success in Post disaster Community Assistance", Science, Technology, \& Human Values. 38(2): 224-249.

Anker, P. 2011. From Bauhaus to Ecohouse: A History of Ecological Design. Baton Rouge: Louisiana State University Press.

Auray, N. and Vétel, B. 2013. "L'exploration comme modalité d'ouverture attentionnelle. Design et regulation d'un jeu freemium". Reseaux. 6. 182: 153-186.

Berque, A. 2000. Ecoumène. Introduction à l'étude des milieux humains, Paris: Belin.

Breviglieri, M. 2012. 'L'espace habité que réclame l'assurance intime de pouvoir: Un essai d'approfondissement sociologique de l'anthropologie capacitaire de Paul Ricoeur". Études Ricoeuriennes / Ricoeur Studies. 3 (1): 34-52.

Calvario, R., and Otero, I. 2015. "Back-to-the-landers". In G. D'Alisa, F. Demaria, and G. Kallis (Eds.),. Degrowth: A Vocabulary for a New Era, Oxon and New York: Routledge. 143-145.

Canguilhem, G. 2006. Le Normal et le pathologique. Paris: PUF.

Casey, E. 1997. The Fate of Place. A Philosophical History. Berkeley and Los Angeles: University of California Press.

acknowledges when he compares gardening to a form of meditation. As explained by Hache (2015), the difficulty, in the modern understanding of political engagement, not to oppose spirituality and emancipation explains the skepticism towards some expressions of ecofeminism, such as that of Starhawk (who is a permaculturist). The importance to be attributed to the spiritual dimension, however, is quite controversial in the permaculture movement itself. See on this point Dawborn and Smith, 2011: 40.

${ }^{92}$ In this sense, an in-depth scrutiny of the different kind of goods that emplacement and detachment can provide the human being with is of paramount importance in social sciences. The research program of "sociology of regimes of engagement" developed by Laurent Thévenot is one of the rare example of a serious investigation of this issue in social sciences. 
Centemeri, Laura, 2018, « Health and the environment in ecological transition: the case of the permaculture movement » in F. Bretelle-Establet, M. Gaille, M. Katouzian-Safadi (dir.), The Relationship between Environment, Health, and Disease Toward a Multi-Spatial and Historical Approach, Springer.

Centemeri, L. and Renou, G. 2015. "The contribution of a pragmatic sociology of valuation to the study of the social movement for sustainable degrowth". Paper presented at the Second European Pragmatism Conference. Paris, September $9^{\text {th }}-11^{\text {th }}$.

Chatterton, P. 2010. "So What Does It Mean to be Anti-capitalist? Conversations with Activists from Urban Social Centres". Urban Studies. 47(6): 1205-1224.

Coste, J. 2014 "Les maladies dominantes au xxe siècle". In B. Fantini and L. L. Lambrichs (Eds.) Histoire de la pensée médicale contemporaine - évolutions, découvertes, controverses, Paris, Le Seuil, 259-278.

Dawborn, K., and Smith, C. (ed.). 2011. Permaculture Pioneers. Stories from the new frontier. Hepburn, Victoria (AU): Melliodora Publishing.

De Laet, M. and Mol, A. 2000. "The Zimbabwe Bush Pump: Mechanics of a Fluid Technology". Social Studies of Science, 30 (2): 225-263.

Dodier, N. and Barbot, J. 2016. "La force des dispositifs". Annales. Histoire, Sciences Sociales. 71, 2: 421-450.

Doidy, E. 2008. “Cultiver l'enracinement. Réappropriations militantes de l'attachement chez les éleveurs jurassiens”. Politix. 83 (3) : 155-177.

Doidy, E. 2012. "Reconstruction personnelle et critique sociale. Enjeux politiques de la réinsertion des anciens combattants par l'agriculture". Lien Social et Politiques, 67 : 33-50.

Ferguson R.S. and Lovell S. T. 2014. "Permaculture for agroecology: design, movement, practice, and worldview. A review". Agronomy for Sustainable Development. Volume 34, Issue 2: 251-274.

Gaille, M. 2011. "L’idée de 'bioéthique globale' : un combat à reprendre ? Le travail de la philosophie et l'histoire tronquée de l'éthique médicale". Cahiers philosophiques. 2,125: 131136.

Gieryin, Th. F. 2000. “A space for place in sociology”. Annual Review of Sociology. 26. 46396.

Hache, E. 2015. "Préface. Where the Future is". In Starhawk. Rêver l'obscur. Femmes, magie et politique. Paris: Cambourakis.

Haenfler, R., Johnson, B., Jones, E. 2012. "Lifestyle Movements: Exploring the Intersection of Lifestyle and Social Movements". Social Movements Studies, 11,1: 1-20.

Hill, S. B. 2011. "Forward" in D. Holmgren. Permaculture. Principles and Pathways Beyond Sustainability. East Meon, Hampshire (UK): Permanent Publications.

Holmgren, D. 2011. Permaculture. Principles and Pathways Beyond Sustainability. East Meon, Hampshire (UK): Permanent Publications. First edition, 2002, Hepburn (Victoria, Australia): Holmgren Design Services.

Hopkins, R. 2011. The Transition Companion: making your community more resilient in uncertain times, Totnes: Green Books.

Jacke D. and Toensmeier E. 2005. Edible Forest Gardens Vol.1. Ecological Vision and Theory for Temperate Climate Permaculture. White River Junction: Chelsea Green Publishing. 
Centemeri, Laura, 2018, « Health and the environment in ecological transition: the case of the permaculture movement » in F. Bretelle-Establet, M. Gaille, M. Katouzian-Safadi (dir.), The Relationship between Environment, Health, and Disease Toward a Multi-Spatial and Historical Approach, Springer.

Lockyer, J. and Veteto, J.R. (ed.). 2013. Environmental Anthropology Engaging Ecotopia. Bioregionalism, Permaculture, and Ecovillagies. New York and Oxford, Berghahn.

Magnaghi, A. 2014. La biorégion urbaine, petit traité sur le territoire bien commun. Paris: Association culturelle Eterotopia France.

Maris, V. 2010. Philosophie de la biodiversité. Petite éthique pour une nature en peril. Paris : Buchet-Chastel.

McGinnis V. (ed.). 1999. Bioregionalism. London: Routledge.

Michael, P. and W. Meachan. 2001. "Permaculture as a Design Modality for Healing and Regeneration: Design with a Deeper Agenda". The Design Journal: An International Journal for All Aspects of Design. 4,2: 42-49.

Mollison, B. 1988. Permaculture - A Designer's Manual. Tyalgum, Australia: Tagari Publications.

Mollison, B. and Holmgren, D. 1978. Permaculture one: a perennial agricultural system for human settlements. Tagari: Tyalgum

Mulligan, M. and Hill, S. B. 2001. Ecological Pioneers: A Social History of Australian Ecological Thought and Action. Cambridge: Cambridge University Press.

Petit, V. 2015. “L'eco-design: design de l'environnement ou design du milieu?". Sciences du design. 2/21: 31-39.

Pink, S. 2009. Doing Sensory Ethnography. London: Sage.

Rosental, C. 2013. "Toward a Sociology of Public Demonstrations". Sociological Theory, 31(4): $343-365$.

Saligram, N., Nugent, R. 2016. "Chronic diseases -- the social justice issue of our time". Lancet, 387(10022): 943.

Schneider-Mayerson, M. 2015. Peak Oil. Apocalyptic Environmentalism and Libertarian Political Culture. Chiacago and London: The University of Chicago Press.

Smith, C. 2002. "Learning for the environment: an examination of personal empowerment through learning permaculture". Post-Script. 3,1:12-25.

Smith, C. 2011. "Introduction". In Dawborn, K., and Smith, C. (ed.). 2011. Permaculture Pioneers. Stories from the new frontier. Hepburn, Victoria (AU): Melliodora Publishing: X$\mathrm{XX}$.

Starhwak. 2002. Webs of power. Notes from the Global Uprising. Gabriola Island: New Society Publishers.

Suh, J. 2014a. "Towards Sustainable Agricultural Stewardship: Evolution and Future Directions of the Permaculture Concept". Environmental Values. 23: 75-98.

Suh, J. 2014b. "Theory and reality of integrated rice-duck farming in Asian developing countries: A systematic review and SWOT analysis". Agricultural Systems, 125: 74-81.

Tassin, J. 2011. “Quand l'agro-écologie se propose d'imiter la nature”. Courrier de l'environnement de l'INRA, 61: 45-53.

Taylor, P. J. 1988. “Technocratic optimism, H. T. Odum, and the partial transformation of ecological metaphor after World War II”. Journal of the History of Biology. 21(2): 213-244. 
Centemeri, Laura, 2018, « Health and the environment in ecological transition: the case of the permaculture movement » in F. Bretelle-Establet, M. Gaille, M. Katouzian-Safadi (dir.), The Relationship between Environment, Health, and Disease Toward a Multi-Spatial and Historical Approach, Springer.

Thévenot, L. 1984. "Rules and implements: investment in forms", Social Science Information. 23(1): 1-45.

Thévenot, L. 2007. "The Plurality of Cognitive Formats and Engagements: Moving between the Familiar and the Public". European Journal of Social Theory. 10(3): 413-27.

Thévenot, L. 2009. "Governing Life by Standards: A View from Engagements". Social Studies of Science. 39 (5): 793-813.

Thibaud, J.-P. 2011. "A sonic paradigm of urban ambiances". Journal of Sonic Studies. 1.1. http://journal.sonicstudies.org/vol01/nr01/a02.

Tuan, Y-F. 1977. Space and Place: The Perspective of Experience. Minneapolis, MN:

University of Minnesota Press.

Turner, F. 2006. From Counterculture to Cyberculture. Stewart Brand, the Whole Earth Network and the Rise of Digital Utopianism. Chicago and London: Chicago University Press.

Yates, L. 2015. Rethinking Prefiguration: Alternatives, Micropolitics and Goals in Social Movements. Social Movement Studies, 14(1): 1-21.

Wall, D. 1998. The No-nonsense Guide to Green Politics. Oxford: New Internationalist. 